would no doubt be correct; but this relation between pressure and rainfall, strange though the fact may appear, does not apparently hold in the winter in the sub-tropical region of Northern India, nor is famine always caused in this region by a failure of summer rain alone.

For as Mr. S. A. Hill has shown in a paper on "Variations of Rainfall "in Northern India" " Indian Meteorological Memoirs," No. vii. p. 204), a heavy winter rainfall generally coincides with a high barometric pressure over Northern India, and vice versâ, while two of the most severe famines in $\mathrm{Mr}$. Chambers' list, viz., those of $1837-38$ and $1860-61$, in Northern India were caused by "a partial failure of the summer rains, followed by an almost complete absence of the usual winter fall."

It is straining the evidence therefore to attempt to relate these famines, as Mr. Chambers has done, to the previous occurrence of high barometric pressures, since if the law just quoted held good, the famine of $1860-61$ was mainly due to the absence of winter rain, caused by the low pressure which observations show actually existed at that time, and the same was very probably the case in $1837 \cdot 38$, a strongly-marked epoch of sun-spot maximum.

It has moreover been shown by Mr. Hill in the paper just referred to that "the summer rains of the North-West Provinces and Rajpootana have failed quite as often when sun-spots were numerous as when they were few, but whereas in the former case a comparatively slight scarcity has generally been developed into a severe famine through the failure of the winter rains, this has seldom happened in the latter case, the distress at such times being alleviated by the in-gathering of the rabi harvest, rendered more abundant than usual by a copious winter fall." This saving clause with respect to the $w$ inter rainfall of Northern India does not unfortunately apply to Southern India, where failure of the usual monsoon simply means drought and probably famine until the next monsoon, i.e. for an entire year.

On the whole it is plain that high and low atmospheric pressures differ specificalily in their effects in different parts of the Indian peninsula, since while the former is generally a:sociated with drought in the southern provinces, the latter in the winter is almost equally fatal in the northern provinces. If therefore the future prevision of famines is to be based on the empirical law connecting high barometric pressure with the occurrence of drought and famine, propounded by $\mathrm{Mr}$. Chambers, it must be remembered that this law strictly applies only to regions where the annual water-supply is dependent upon the monsoons alone, and therefore lying for the most part between the two tropics.

It niay be remarked that at least half of the Indian peninsula lies north of the tropic of Cancer.

Though I am sceptical as to the idea of motion from west to east, conveyed by the existence of a lag at the more easterly stations, this in no way affects the possibility of prevision as long as the lag remains fairly constant. I am therefore of opinion that in regard to this question the evidence furnished by Mr. Chambers is exceedingly valuable, and that so long as districts are only taken into account that lie within the tropics, such as Southern India, the possibility of prevising famines by noting the occurrence of barometric maxima at more westerly stations may in time be accomplished. For Northern India, and pro. bably other similar sub-tropical regions, the matter is at present more complicated.

E. DOUglas ARCHibald

P.S.-In the preceding letter I have only dwelt upon the limitation to be applied to $\mathrm{Mr}$. Chambers's conclusions in the case of Northern India. It is obvious however that there are at least two distinct difficulties to be explained, before they can be finally accepted, even for countries within the Tropics, viz. (I) Why the barometric waves should commence on one meridian rather than on another, and (2) if, as Mr. Chambers thinks, the waves of pressure travel slowly round the earth, why they do not reappear at the place where they started after an interval of about one year and eight months (calculated from the lags given in Mr. Chambers's paper). At present there does not appear to be the slightest evidence to show that they reappear at all, and if they do not, when and where do they disappear?-E. D. A.

Mr. E. D. ARChibald states in his friendly criticism of my paper on "Abnormal Variations of Barometric Pressure in the Tropics, and their Relations to Sunspots, Rainfall, and Famines," that the occurrence of a decided lag in the barometric movements at easterly, as compared with westerly stations, conld only be utilised to previse famines if we knew for certain that famines in those districts to which the method is applied invariably took their rise from one set of conditions, such as failure of the usual summer rains, preceded and accompanied by high barometric pressure. It appears to me, however, that if the variations of the rainfall can be: definitely related in any manner to the corresponding variations of the barometric pressure, there is no necessity for such a limitation. If, for instance, in Northern India, "a heavy winter rainfall generally coincides with a high barometric pressure, and vice vers $\hat{a}$," as Mr. Archibald seems prepared to admit, then the occurrence in the winter of a high pressure would portend a heavy winter rainfall, and vice versa, and in this case the failure of the winter rains might be foreseen by observing the progress eastward of the barometric minima.

But I am not aware that the relation above mentioned between the barometric pressure and the winter rainfall of Northern India has yet been worked out with sufficient definiteness for the purpose in view, for although there does appear to be some evi dence in favour of that relation when the average pressure and the total rainfall of the whole winter are taken into account, yet on the other hand it is now known that the short rainy feriods of the winter are periods of relatively low pressure. It is not improbable that these periods of low pressure, and the rainfall which acconpanies them, are connected with the feeble cyclonic disturbances which (as appears from the charts of stormtracks published by the American Government) occasicnally enter the north-west of India in the winter months and travel down the Ganges Valley sometimes as far as Bengal. The facts concerning these winter rains seem to accord far better with this view of their origin than with the old notion of their connection with the upper anti-monsoon current, an idea which I observe has now been abandoned by $\mathrm{Mr}$. Blanford, the Meteorolugical Reporter to the Government of India, although up to a recent date it was still retained by some other Indian meteorologists. The question is as yet involved in much obscurity, and I must, with the alove suggestion, leave it to be dealt with by those more immediately concerned.

But whatever the relation between the winter rainfall and the barometric pressure may be, I cannot help thinking that $\mathrm{Mr}$. Archibald attaches an exasgerated relative imporiance to these winter rains, for, from the register of Allahabad, the capital of the province, it appears that the winter rain amounts on the average to only $1.54^{\prime \prime}$, whereas the average summer rain amounts to $36^{\circ} 84^{\prime \prime}$. And similarly at Delhi, the average total winter rain is only $3^{\circ} \mathrm{II}^{\prime \prime}$, while that of the summer is no less than $24^{\circ} 60^{\prime \prime}$. Such being the case, I think it would be difficult to prove that "the famine of $\mathrm{x} 860-6 \mathrm{I}$ in the North-West Provinces was mainly due to the absence of the winter rain," more especially as the summer rain of 1860 in that province was deficient to the extent of nearly one-half, the fall having amounted to only 54 per cent. of the average.

Neither does it seem clear why the methods of forecasting the general character of a coming season, which are suggested in my paper, should of necessity be applicable only to intertiopical regions. It is true that $I$ have dealt only with barometric data furnished by stations lying within the tropics, but my only reacon for doing so was that there seemed a better prospect of obtaining definite results from the records of tropical stations, where the weather is generally of a comparatively settled character, than from those of stations situated in extra-tropical regions, where the weather is generally more disturbed. Indeed I am not without hope that the results I have obtained will induce European meteorologists to take up the subject with a view to the possibility of prevising the general character of coming seasons in Europe from observations recorded in America.

Fred. Chambers

\section{STANDARD THERMOMETERS}

DEAR SIR,-The Kew Committee have instructed me to forward you the enclosed Memorandum on Standard Thermometers, and to request on their behalf that you would be so good as to publish it in NATURE if you consider it suitable for insertion.

Kew Observatory, Richmond, Surrey, February 9

DR. LEONARD WALDO has recently communicated to the American Tournal of Science an article entitled "Papers on Thermometry from the Winchester Observatory of Yale College." 
In it he treats of the errors of three standard thermometers con. structed for him at the Kew Observatory, and after describing minutely the instruments, the manner in which he verified the accuracy of the positions of the fixed points, and the appliances he used in the work, proceeds to state that he then rigorously examined the thermometers for errors depending on calibration. Of these he says : "The results of our calibration are given in the following table. The observations were made with Apparatus II., and special care was taken to guard against any changes of temperature. The reduced results are as follow's, where each line is the mean of three observations:-

\begin{tabular}{|c|c|c|c|c|}
\hline $\begin{array}{l}\text { Thermo- } \\
\text { meter. }\end{array}$ & Date. & $\begin{array}{l}\text { Extreme } \\
\text { readings. }\end{array}$ & $\begin{array}{c}\text { Com- } \\
\text { puted } \\
\text { length of } \\
\text { col. }\end{array}$ & $\begin{array}{l}\text { Correction for } \\
\text { calibration error. }\end{array}$ \\
\hline Kew, $57^{8}$ & $\begin{array}{l}\text { I880. } \\
\text { Oct. I } 5\end{array}$ & $\begin{aligned} & 0 \\
-\quad & 1 \cdot 3+0 \\
+ & 31 \cdot 0+65 \cdot 1 \\
+ & 63 \cdot 7+98 \cdot 6\end{aligned}$ & $\begin{array}{l}32 \cdot 487 \\
32 \cdot 507 \\
32 \cdot 487\end{array}$ & $\begin{aligned} \text { At } 3^{\circ} \mathrm{C} . & =+0^{\circ} 007 \\
65 \mathrm{C} . & =-0^{\circ} 014 \\
99 \mathrm{C} . & =+0^{\circ} 007\end{aligned}$ \\
\hline Kew, 584 & Oct. 15 & $\begin{array}{l}+32^{\prime} \cdot 2+82 \cdot 3 \\
+76 \cdot 1+127 \cdot 3 \\
+119 \cdot 1+170 \cdot 1 \\
+162 \cdot 2+213 \cdot 2\end{array}$ & $\begin{array}{l}49^{\circ} 040 \\
49^{\circ} 068 \\
49^{\circ} 078 \\
49^{\circ} 060\end{array}$ & $\begin{array}{r}79 \mathrm{~F} .=+0.02 \mathrm{r} \\
\mathrm{r} 23 \mathrm{~F} .=-0.006 \\
166 \mathrm{~F} .=-0.016 \\
212 \mathrm{~F} .=+0^{\circ} 001\end{array}$ \\
\hline $\mathrm{Kew}, 5^{8} 5$ & Oct. I5 & $\begin{array}{r}-10^{\circ} 0+50^{\circ} 9 \\
+\quad 49^{\circ} 0+100^{\circ} 9 \\
+\quad 99^{\circ} 1+15^{\circ} 7 \\
+148.9+2010^{\circ} 0 \\
+199^{\circ} 2+20^{\circ} 8\end{array}$ & $\begin{array}{l}49 \cdot 813 \\
49 \cdot 843 \\
49 \cdot 820 \\
49 \cdot 807 \\
49 \cdot 747\end{array}$ & $\begin{aligned} 50 \mathrm{C} . & =+0^{\circ} 015 \\
100 \mathrm{C} . & =0.000 \\
150 \mathrm{C} . & =+0^{\circ} 008 \\
200 \mathrm{C} . & =+0.029 \\
250 \mathrm{C} . & =+0^{\circ} 110\end{aligned}$ \\
\hline
\end{tabular}

REMARKS. - The observations were all made by daplight, and at one sitting for each thermometer. The extreme variations of the temperature of the room during the observations as measured by two thermometers, one at each end of the tube being measured, were as follows :-

$$
\text { Kew, } \begin{aligned}
578 & =0 \circ \mathrm{F} . \\
584 & =0.1 \mathrm{~F} . \\
585 & =0.1 \mathrm{~F} .
\end{aligned}
$$

The length of the column used for the Kew calibration, and by which the thermometers were graduated, was $5^{\circ} \circ 026 \mathrm{C}$. for Kew $578,10^{\circ} 405 \mathrm{~F}$. for 584 , and $10^{\circ} \cdot 673 \mathrm{~F}$. for Kew 585 . We may therefore conclude that between $0^{\circ}$ and $100^{\circ} \mathrm{C}$. the errors of the three Kew standards depending on the calibration are practically insensible; for the errors shown above are too small to be certainly detected, owing to the width of the lines which make up the graduation of the thermometer scales.

Accidental errors of graduation could not be guarded against except by the direct examination of every degree, and that accordingly has been done.

The tedious exanination of each degree was accomplished with the aid of Prof. J. E. Kershner. We used the apparatus I., and each degree was measured twice. The resulting means were expressed in terms of hundredths of one division of the eye-piece micrometer, and gave a subdivision of about $\frac{1}{435}, \frac{1}{23}$, and $\frac{1}{2100}$ of $1^{\circ}$ in the cases of Kew 578, 584, and 585 respectively. There were about 2300 separate micrometer readings made, and the result of the reductions shows that no sensible accidental errors have been introduced into the graduations of these stanlards.

\section{UNIVERSTTY AND EDUCATIONAL INTELLIGENCE}

CAMBRIDGE.-The latest edition of the schedule of subjects for the Moral Sciences Tripos fully recognises physiology. In the advanced part of the examination special knowledge is required (I) of the physiology of the senses and of the central nervous system; (2) of experimental investigations into the intensity and duration of psychical states ; and (3) of such facts of mental pathology as are of psychological interest. Questions will also be set relating to the philosophic treatment of the relation of body and mind as regards both the method and the general theory of psychology. Mr. Lewes's "Problems of Life and Mind," vols. iii.-v., Dr. Michael Foster's "Text-book of Physiology," Book iii., Wundt's "Physiologische Psychologie," Fechner's "In Sachen der Psychophysik," Maudsley's " Physio- logy of Mind " and "Pathology of Mind" are among the books recommended.

Mr. J. M. H. Munro, D.Sc. Lond., F.C.S., has been elected resident Professor of Chemistry in the Wilts and Hants Agricultural College, Downton, Salisbury, and he will act in co-operation with Prof. A. H. Church, M.A.Oxon. Dr. Munro headed the list in first-class honours in chemistry at both of the examinations for the B.Sc. degree, and obtained the chemical exhibition of the University in I874. He was also classed in botany and vegetable physiology, and in logic and moral philosophy, and took the Doctor's degree in 1877 . He recently received a grant from the Chemical Society in aid of a research on which he is at present engaged.

\section{SCIENTIFIC SERIALS}

THE Proceedings of the Royal Irish Academy ("Science"), part 5, vol. iii., series II, December, I 880 , contains--W. R. Roberts, on the satellite of a line meeting a cubic.-A. H. Anglin, mathematical notes.-Prof. J. P. O'Reilly, on the directions of main lines of jointing observable in the rocks about the Bay of Dublin, and their relations with adjacent coast-lines;-also on the correlation of the lines of faulting of the Palamow coal-field district, Northern India, with the neighbouring coast-lines.-Prof. E. Davy, preliminary report on some new organic nitroprussides.Prof. W. King, preliminary notice of a memoir on rock-jointing in its relation to phenomena in physical geography and physical geology.-J. F. Knott, on some anomalies in human anatomy (woodcuts).--Prof. Mackintosh, note on the occurrence of a premaxillo-frontal suture in the skull of the koala (Phascolarctos cinereus (with plates ro to 13 ).-G. H. and G. A. Kinahan, eurites or basic felstones of Silurian age. $-G . H$. Kinahan, sup posed Upper Cambrian rocks in the counties of Tyrone and Mayo.

The Proceedings of the Royal Irish Academy.--"Polite Literature and Antiquities," part 2, vol. ii. series II, December, 1880, contains the following papers of interest to the student of nature :-W. Frazer, description of a great sepulchral mound near Donnybrook (in Co. Dublin), containing human and animal remains, as well as some objects of antiquarian interest referable to the tenth or twelf th centuries (woodcuts).-G. Allmann Armstrong, particulars relative to the finding of human remains in the neighbourhood of Dundalk (woodcut).-R. J. Ussher and G. H. Kinahan, on a submarine crannog at Ardmore, Co. Waterford (plate $I$ and woodcut). - Thos. Plunkett, on an ancient settlement found about twenty-one feet beneath the surface of the peat in the coal-bog at Boho, Co. Fermanagh (plate 2).

THE Scientific Proceedings of the Royal Dublin Society, vol. ii. new series, part vii., November, 1880, contains :--V. Ball, on the mode of occurrence and distribution of diamonds in India. A. B. Wynne, on some points in the physical geology of the Dingle and Iveragh Promontories.-Dr. C. A. Cameron, on the action of water upon mercuric sulphate.-J. H. Luby, voluntary act of self-destruction by the worker bee.-G. F. Fitzgerald, F.I.C.D., notes on fluorescence.-Thos. Plunkett, on chert in the limestone of Knockbeg, county of Fermanagh (woodcut). R. M. Barrington, M.A., on the introduction of the squirrel into Ireland (with a map).

Vol. iii., new series, part i., January I88I, contains :-C. E. Burton and Howard Grubb, on a new form of ghost micrometer for use with astronomical telescopes (plates I to 4).-E. T. Hardman, on a travertine from Ballisodare near sligo, containing a considerable amount of strontium.-W. Smith, preliminary note on the manufacture of paper from melic grass (Molinia carulea).-D. M'Ardle.-On some new or rare Irish Hepaticæ (with plates 5 and 6).-Percy Evans Freke, on North American birds crossing the Atlantic (with tables).

Journal and Proceedings of the Royal Society of New South Wales, vol. xiii., 1879 (Agents in London Messrs. Trübner and Co.), contains-On the "gem" cluster in Argo, by H. C. Russell.-On the water of Sydney Harbour, by the Rev. W. H. Sharp.-On the anatomy of Distichopora, with a monograph of the genus, by Rev. J. E. Tenison-Woods (two plates).-On the geological formations of New Zealand compared with those of Australia, by Dr. Jas. Hector.-On the languages of Australia in connection with those of the Mozambique and of the south of Africa, by Hyde Clarke.-On Ottelia praterita, F. v. M., by Baron von Muiller, with a plate (an alisma-like leaf-impression from the green-bush quarry near to Parramatta, apparently allied 